\title{
2 Theoretical Considerations: Identity and Conflict
}

\subsection{Reflections on the Concept of Identity}

The perception of 'oneself' and 'others' represents a central aspect in social interaction and thus in interreligious encounters. How one sees and presents oneself and experiences oneself in the encounter with others influences how one is perceived by the other. This in turn indirectly influences the self-perception of the other and also affects interactions. Depending on whether one accepts the concept of a stable identity or that of multiple identities, one will see interreligious educational processes differently and organise them differently, when it is viewed as possibly dangerous.

Therefore, in order to adequately grasp interreligious educational processes, we will examine interaction patterns against the background of social psychological and social-scientific identity models. We will pose the question as to what role personal and social identity and the perception of the other play and how they influence the interreligious encounter positively or negatively.

So that we can address the question of identity, the theoretical framework that underlies our reflections will be discussed first. 'Identity' goes back to the Latin word idem and means 'the same.' As a philosophical concept, identity means that 'something must be the same as something else in all aspects and distinct from others' ${ }^{1}$. Since the establishment of the concept of identity by specialists in the $18^{\text {th }}$ century, the models of and properties of the concept have changed. Up until the present the question of identity has been at the centre of the discussion about identity: 'Who am I?"2 Various processes of social change, which accompany the conditions and consequences of modernity, offer new answers and possibilities to the old questions of identity. Processes of social differentiation, the pluralisation of lifeworlds, and the concomitant individualisation process lead to the detachment of the individual from preconceived societal frameworks.

At the same time, identity discourse has experienced a boom in recent years, as shown by the numerous social-scientific and psychological publications, that

1 Niethammer, Lutz, Kollektive Identität. Reinbek 2000, 41.

2 Straub, Jürgen, Identitätstheorie, empirische Identitätsforschung und die ,postmoderne‘ armchair psychology. In: Zeitschrift für qualitative Bildungs-, Beratungs- und Sozialforschung (2000) 1, 167-194, here 170.

๑ OpenAccess. (c) $2022 \mathrm{Kraml}$, Sejdini, Bauer, Kolb, published by De Gruyter. (cc))BY-NC-ND This work is licensed under the Creative Commons Attribution-NonCommercial-NoDerivatives 4.0 International License. https://doi.org/10.1515/9783110762877-004 
indicates the relevance of the theme. ${ }^{3}$ The question of 'individual' or 'personal' identity has been discussed from various perspectives, especially in (social) psychology. In empirical studies on identity, psychology focuses on the analysis of cognitive self-images. Education looks at the possibilities of self-development while, from the social-scientific perspective, the social presuppositions for concepts of identity are reconstructed. ${ }^{4}$ Viewed from the perspectives of the various sciences, identity can be understood 'as a (cognitive) self-image, as habitual impression, as social roles, or as ascription, as performative service, as a constructed narrative, ${ }^{5}$. In what follows, we will elucidate the perspectives of identity research that are central to our own research, which are also reflected in our evaluation of the empirical material.

\subsubsection{Psychological Perspectives on Identity}

The German-American psychoanalyst and developmental psychologist Erik Erikson (1902-1994) influenced the present psychological concept of identity in a significant way. He was the first to develop a psychologically based identity model, conceived as a

fundamental attitude that a young person had to form at the end of his youth from the successful synthesis of the post-adolescent organisation of the urges of his I and social reality. ${ }^{6}$

The 'I identity" that develops at the end of post-adolescence ${ }^{8}$ is characterised, according to Erikson, as a uniform and 'stable' essential core that secures a more or less successful management of life after adolescence. ${ }^{9}$ Erikson's identity theory is a psychological development model that he considers to be the foundation of personality development. In this model, identity is a partial aspect of personality and the final step in the development of the I that takes place

3 Cf. ibid., 169f.; Eickelpasch, Rolf / Rademacher, Claudia, Identität. Bielefeld 2004, 5.

4 Cf. Zirfas, Jörg, Identität in der Moderne. Eine Einleitung. In: Jörissen, Benjamin / Id. (eds), Schlüsselwerke der Identitätsforschung. Wiesbaden 2010, 9-18, here 9.

5 Ibid.

6 Erikson, Erik H., Das Traummuster der Psychoanalyse. In: Psyche (1955) 8, 561-604, here 601.

7 Cf. Erikson, Erik H., Identität und Lebenszyklus. Frankfurt/Main 1973; Erikson, Erik H., Jugend und Krise. Stuttgart ${ }^{3} 1980$.

8 The concept of post-adolescence characterises early adulthood and lasts from the age of 18 to 24 according to Erikson's model of psychosocial development.

9 Cf. Erikson, Identität und Lebenszyklus, $107 \mathrm{f}$. 
in the first three life phases. ${ }^{10}$ This step includes all significant identifications. ${ }^{11}$ Erikson identifies eight life phases that assign specific tasks to the individual to master crisis situations. To that extent, his model is significant for the evaluation of our empirical material since it is also frequently used in religious education today. This model is the foundation for the understanding of the development of students, especially in educational and developmental processes. Above all, this is important because,

beyond the horizon of objectives related to content but obviously also motivated and supported by them, [religious instruction makes] a universally human contribution to children and young people finding their identity. ${ }^{12}$

Although Erikson does not formulate an explicit theory of religion, his model of religious education was adapted to describe processes of the development of religious identity. ${ }^{13}$ Moreover, Erikson's concept has also had lasting influence on the progress and continued development of psychological and social-scientific theories of identity. The focus on the processual character of psycho-social development as well as the idea of a lifelong development of the human being has been valuated positively. In the context of postmodern identity discourse, the idea of identity as a stable essential core, which continues to exist into adulthood has, however, been criticised in particular. ${ }^{14}$

In addition to its significance in the various scientific disciplines, Erikson's model is important for the social-scientific analysis of the present data in connection with the question of what self-image emerges with regard to one's own religious identity and how these fundamental ideas can also be identified in the narrations of the interviewees.

10 Cf. Noack, Juliane, Erik H. Erikson. Identität und Lebenszyklus. In: Jörissen / Zirfas (eds), Schlüsselwerke der Identitätsforschung, 37-54, here 45.

11 Cf. Erikson, Jugend und Krise, 156.

12 Mendl, Hans, Religionsdidaktik kompakt: Für Studium, Prüfung und Beruf. Munich 2012, 71. 13 Cf. ibid., 34.

14 James E. Marcia operationalised Erikson's phase model for empirical research and developed an expanded identity theory, at whose centre are four states of human identity (cf. Marcia, James E., The ego identity status approach to ego identity. In: Id. / Waterman, Alan / Matteson, David / Archer, Sally / Orlofsky, Jacob (eds), Ego identity. A handbook of psychosocial research. New York 1993). 


\subsubsection{Social Psychological Models: Identity as Narration}

We will use the concept of patchwork identity to examine the narrations and identity constructions of the interviewees. This model was developed by Heiner Keupp and his research group on the basis of empirical studies in order to get a theoretical grasp of identity negotiations in contemporary circumstances. For our analysis, Keupp's approach represents a useful theoretical foundation because, on the one hand, self-narrations are present in the interviews, and, on the other, the plural and religiously heterogeneous situation of our interviewees requires a strategy that directs our focus on the construction of identity in the sense of images of oneself and of the other. The approach of patchwork identity permits us to, among other things, focus on partial aspects of identity, like that of religious identity. Guiding questions here are how one's own religious identity is developed and 'narrated' and how the religious identity of the other is perceived and represented. ${ }^{15}$

Keupp's identity model is directed at the 'deconstruction of founding co-ordinates of modern self-understanding' like the 'ideas of the unity, continuity, developmental logic or progress ${ }^{16}$ of identity. Keupp is a postmodern representative of identity research who demonstrate the processes of social change and the concomitant chances and risks for individual identity negotiation. In distinction from modern identity models like Erikson's, which view identity as a stable core in an unvarying socio-cultural environment, representatives of postmodern identity theories criticise the 'ideal of a successful integration of subject and society' and refer to 'the impossibility of such a synchronisation in a capitalist society $^{\prime 17}$.

The processes of differentiation, individualisation, and pluralisation that have been ascertainable since the 1960s and lead to the loss of meaning and the dissolution of traditional communities in the sense of identity-guaranteeing ways of life, ${ }^{18}$ compel the individual into a more active role in shaping his or her life and in the attribution of meaning. Thus, the 'processing of different roles, ways of life, and elements of meaning into a whole of meaning is demanded as one's own contribution and task.'19

15 Cf. Bauer, Nicole M., Kabbala und religiöse Identität: Eine religionswissenschaftliche Analyse des deutschsprachigen Kabbalah Centre. Bielefeld 2017, 57-65.

16 Keupp, Heiner, Identitätskonstruktionen. Das Patchwork der Identitäten in der Spätmoderne. Reinbek ${ }^{4} 2008,30$.

17 Ibid., 29.

18 Cf. Eickelpasch / Rademacher, Identität, 6.

19 Ibid., 7. 
It is precisely those processes of active construction that are the focus of late modern identity research. ${ }^{20}$ Moreover, with respect to the identity model, it is primarily the notion of a 'seamless integration of the subject into the respective socio-cultural environment'21 and the assumption of an 'complete internal psychological integration of the personality' that are critiqued. ${ }^{22}$ Here, Keupp picks up on, among other things, Theodor W. Adorno's notion of the 'end of the compulsion of identity'23, which emphasises that the individual has the opportunity to form his/her own self-image, without being subjected to pregiven role constraints and models of normality that aim at the 'unity' of the personality. ${ }^{24}$ Furthermore, Keupp puts the focus on the creative potential that lies in the active process of identity negotiation ${ }^{25}$ and allows the individual the possibility of functioning as the builder of one's own container for one's life. ${ }^{26}$ He characterises identity as

the individual conceptual framework of a person within which one interprets one's experiences and that provides a basis for everyday identity negotiation. ${ }^{27}$

This daily identity negotiation consists in 'matching' internal and external experiences and linking various partial identities. ${ }^{28}$ Thus, identity negotiation also happens in and through the interaction with others and in 'patchworking' different aspects of identity. Identity negotiation is, accordingly, also a conflict negotiation whereby a 'conflict-oriented state of tension' is reached by finding a subjectively coherent fit between internal and external aspects. At the same time, identity formation is an ongoing, open-ended process of linking experiences to-

20 The American philosopher George Herbert Mead and other representatives of the so-called 'symbolic interactionism' of the 1950s and 1960s held that identity was to be understood as a process of negotiation and ascription. They argued for the idea of the constructed character of identity (cf. Mead, George Herbert, Geist, Identität und Gesellschaft aus der Sicht des Sozialbehaviorismus. Frankfurt/Main $\left.{ }^{17} 1973\right)$. The concept of identity developed by Mead describes identity as the 'relation between personal identity and (internalised external) social expectations' (Laack, Isabel, Religion und Musik in Glastonbury. Eine Fallstudie zu gegenwärtigen Formen religiöser Identitätsdiskurse. Göttingen 2011, 34). According to this concept, personal identity arises only 'in interaction and communication with other subjects' (ibid.).

21 Keupp, Identitätskonstruktionen, 16.

22 Ibid.

23 Cf. Adorno, Theodor W., Negative Dialektik. Frankfurt/Main 1966, 175.

24 Cf. Keupp, Identitätskonstruktionen, 17.

25 Cf. ibid., 28

26 Ibid., 55.

27 Ibid., 60.

28 Cf. ibid., 7. 
gether, ${ }^{29}$ which occurs only in narration by means of self-narration. It is important to keep in mind that narrative structures, the ways by which an individual sorts his/her experiences and integrates them into the self-image, are socially and culturally influenced. ${ }^{30}$

For the assessment of the interview material, the aspect of the constructed character of identity is also helpful on the one hand for examining the narrations as such. On the other hand, we want to understand the dynamics and structures that lie behind the constructions and their social and cultural conditionality particularly with respect to religiosity as a central part of identity.

\subsubsection{Sociological Aspects of Identity: Identity and Community}

\section{Personal, Collective, and Cultural Identity}

To understand the constructions of identity in contexts like interreligious educational processes, another element is needed, namely, social or collective identity. Two aspects play an essential role here in the analysis: on the one hand, identification with a specific social group or the feeling of belonging to a certain group such as a certain religious community and delimitation from others ${ }^{31}$ and establishing lines of demarcation on the other. To clarify this, the perspectives and models of personal identity discussed above regarding the aspect of cultural and social identity will be expanded and some theoretical perspectives introduced that are necessary for the analysis of interreligious educational processes and the conflicts that arise in them.

Cultural studies in particular - as well as sociology - explores the connection between culture, society, and the subject. Here, it is less the concept of iden-

29 Cf. ibid., 197.

30 Cf. ibid., $207 \mathrm{f}$.

31 The concept of the other is often linked to the concept of the stranger in religious education. In the literature, this connection is frequently critically discussed, as, for example, in the works of Georg Auernheimer (Auernheimer, Einführung in die interkulturelle Erziehung), Erol Yildiz (Yildiz, Erol, Konstruktion des Anderen als ethnisch Fremder: Zur Notwendigkeit eines Perspektivenwechsels in der interkulturellen Bildung. In: Karakasoglu, Yasemin / Lüddecke, Julian [eds], Migrationsforschung und Interkulturelle Pädagogik. Aktuelle Entwicklungen in Theorie, Empirie und Praxis. Münster 2004, 145-157) or Paul Mecheril (Mecheril, Paul, Prekäre Verhältnisse. Über natio-ethno-kulturelle [Mehrfach-]Zugehörigkeit. Münster 2003). In line with these works, we also take a critical view of the construction of the stranger or of strangeness because linguistic differences are cemented and ontologised here. Consequently, we do not use the concept of 'strangeness' or 'the strange/stranger' but the concepts 'otherness', 'the other', or 'the religious other'. 
tity that is in the foreground than the concept of subject. At the same, the 'entire cultural form ... in which the individual as a physical-spiritual-emotional entity becomes a social being in specific practices and discourses ${ }^{32}$ is subsumed under this concept of subject. Identity is thus understood as a particular expression of the subject form, as

the way in which a specific self-understanding, a self-interpretation is built into this cultural form, whereby this identity is always linked, directly or indirectly, with a marking of differences from cultural others. ${ }^{33}$

As a marking of difference, as the delimitation from others or strangers, identity is the basis of collective identity construction. ${ }^{34}$ Moreover, fundamental personal identities are to be distinguished from collective 'we' identities. By the latter we understand, following Jan Assmann,

the image that a group constructs of itself and with which its members identify. Collective identity is a question of the identification on the part of the participating individuals. There is no 'group in itself' but only to the extent that specific individuals affirm it. It is as strong or weak to the extent it exists in the consciousness of the group's members and is able to motivate their thinking and actions. ${ }^{35}$

Because of processes of social change and political developments in the late modern period, modern collective identities like 'nation, 'class', 'gender', 'ethnicity' or 'religion' have also partly lost the power of stabilisation. ${ }^{36}$ One of the most far-reaching consequences of the above-mentioned social changes can be seen in the disintegration of traditional connections and communities. Thus, viewed in terms of society as a whole, collective identities have also lost efficacy for orientation and identification. The British sociologist Stuart Hall speaks in

32 Reckwitz, Andreas, Subjekt. Bielefeld ${ }^{2} 2010,17$.

33 Ibid.

34 We follow an anti-essentialist approach also with respect to the understanding of collective identity, thus emphasising the construction character of identity and not viewing this as an obvious given.

35 Assmann, Jan, Das kulturelle Gedächtnis. Schrift, Erinnerung und politische Identität in frühen Hochkulturen. Munich ${ }^{6} 2007,132$.

36 Comprehensive representations of the collective identities of ethnicity and culture can be found in the works of Stuart Hall. On this, see: Hall, Stuart, Die Frage der kulturellen Identität. In: Id. (ed), Rassismus und kulturelle Identität. Ausgewählte Schriften. Hamburg 1994), 180 222; Hall, Stuart, Ethnizität. Identität und Differenz. In: Engelmann, Jan (ed), Die kleinen Unterschiede. Der Cultural Studies-Reader. Frankfurt/Main 1999, 83-98; Hall, Stuart, Rassismus und kulturelle Identität. Hamburg ${ }^{4} 2008$. 
this context of the decentering and relativisation of comprehensive stable identities in postmodernism. ${ }^{37}$

Through the loss of the significance of effective collective identities, as noted by social scientists, the individual is forced into the active role of creating references and basic conditions for his or her own life. Consequently, a great freedom of action now exists in specific social areas with respect to the choice of communities that one identifies with. The identification with different collectives is thus

subject to the subjective dynamics of personal identity negotiation, and the significance of that for the individual is no longer as powerful as the erstwhile influence of the community. ${ }^{38}$

Nevertheless, communities are central markers of identification for the individual. ${ }^{39}$ Identification with a specific group leads in turn to demarcation from others. ${ }^{40}$

The construction of the other is a central concern in the analysis of the empirical material here presented and is indispensable for the understanding of interreligious educational processes. Stuart Hall developed a far-reaching model for the analysis and the understanding of cultural identity, at whose centre is the construction of the 'other' and the latter's influence on oneself, one's personal identity. ${ }^{41}$ Identity is created as a narration of the self within a discourse through the construction of difference and is a continuing process. ${ }^{42}$ Hall describes those areas "from which our "affiliation" with a distinct, ethnic, "racist", linguistic, religious, and above all national cultures" ${ }^{33}$ arises as 'cultural identity'.

37 Cf. Hall, Ethnizität, 90.

38 Pirker, Vera, Fluide und fragil. Identität als Grundoption zeitsensibler Pastoralpsychologie. Ostfildern 2013, 157.

39 Mead had already established that identification with a specific group enhances the individual's personality, and that in turn strengthens the individual (cf. Mead, Geist, Identität und Gesellschaft aus der Sicht des Sozialbehaviorismus, 363).

40 Cf. Kolb, Jonas, Präsenz durch Verschwinden. Sprache und Ethnizität in der Alltagspraxis junger Kärntner Slowen_innen. Bielefeld 2018, 101-137.

41 He explains his theory of cultural identity by using the example of racism. Hall views racism as 'a structure of discourse and representation that seeks to expel the other symbolically' (Hall, Ethnizität, 94).

42 Cf. ibid.

43 Hall, Die Frage der kulturellen Identität, 180. 
Belonging to a (religious) community creates a 'fictitious imaginary we', which brings about a demarcation externally from the 'other'. ${ }^{44}$ The construction of the identity of the other, the stranger, happens in the same way as one's own personal identity is constructed. Concepts of 'othering' take up this problem. ${ }^{45}$ The process of the construction of collective identity thus contains the identification with oneself as well as the external demarcation. Stuart Hall refers in this connection to the significance of the other for oneself.

The encounter with the religious other is a central aspect in interreligious educational processes. A reciprocal influence occurs between the 'I' and the 'other', which becomes visible in the communicative processes of negotiation. At the same time, precisely this confrontation contains substantial conflict potential, which is the focus of our research.

\section{Social Identity}

In interreligious educational processes, individuals are constantly challenged through their experiences with 'boundaries' - challenged to concern themselves with their religious identity and to defend it when appropriate. ${ }^{46}$ The boundary becomes the central place where identity as a whole and religious identity (as part of one's identity) are primarily negotiated. A theoretical concept that is useful for the evaluation and discussion of our empirical material is the model of 'social identity'. This concept allows us to analyse the social interaction processes in the different religious groups and the concomitant evaluation. Henri Tajfel, ${ }^{47}$ who derived his theory from group experiments, developed a comprehensive group theory that allows him to describe social interaction processes with a particular focus on social identity.

For this, he developed a model of identity that directs his focus in particular to this boundary, the transition from inside to outside. With the term 'self-concept', he describes two aspects of identity: 'personal identity' and 'social identity'. ${ }^{48}$ Social identity includes that aspect of self-understanding that

44 Cf. Eickelpasch / Rademacher, Identität, 68.

45 Cf. Mecheril, Paul / Scherschel, Karin / Schrödter, Mark, 'Ich möchte halt nur wissen, wie es ist, du zu sein'. Die Wiederholung der alienierenden Zuschreibung durch qualitative Forschung. In: Badawia, Tarek / Hamburger, Franz / Hummrich, Merle (eds), Wider die Ethnisierung einer Generation. Beiträge zur qualitativen Migrationsforschung. Frankfurt/Main 2003, 93-110.

46 Cf. Pirker, Fluide und fragil, 393.

47 Tajfel, Henri, Gruppenkonflikt und Vorurteil. Bern 1982.

48 Cf. Güttler, Peter O., Sozialpsychologie. Munich ${ }^{3} 2000,162$. 
derives from his/her knowledge about his/her membership in social groups and from the value and emotional significance with which this membership is occupied. ${ }^{49}$

Through belonging to a social group, individuals divide their social world into an 'in-group' and an 'out-group'. Because individuals strive for a positive valuation of their self-understanding and this in turn is influenced by membership in a social group, one's own group has a more positive valuation attached to it than the out-group..$^{50}$ Here, it is important that the positive assessment of the in-group happens 'only in relation to perceived differences from the other group and the value connotations of this difference. ${ }^{51}$ Social comparisons are thus indispensable for the positioning of one's own group and for the reinforcement of the self-image of the group.

The theory of social identity is necessary and helpful especially in the area of interreligious education in order to register processes of interaction between different religious groups - in our case between Muslims and Catholic students - and to interpret their narrations in reference to their own and the other religion. This offers a theoretical foundation for analysing conflicts that emerge in interreligious encounters and the conditions under which they develop and for gauging the conflict potential that lies precisely in these processes of negotiation and delimitation.

\subsubsection{Identity from the Perspective of Theology}

The concept of identity plays an important role precisely in theological contexts and is expressed in various concepts and aspects. From this perspective, religion functions fundamentally as a constitutive determinant of identity. ${ }^{52}$ How this concept is used in the religious context depends above all on two factors. On the one hand, it comes down to, as was explained above, how the relation to oneself/to one's own religion or to one's own faith is conceived. If this is related exclusively to one's own development, to the intrareligious context, and it is accompanied by a static view of identity, then this religious other is considered more of a threat.

49 Tajfel, Gruppenkonflikt und Vorurteil, 102.

50 Cf. ibid., 159.

51 Ibid., 106.

52 Cf. Schweitzer, Friedrich, Entwicklung und Identität. In: Bitter, Gottfried et al. (eds), Neues Handbuch religionspädagogischer Grundbegriffe. Munich ²2006, 188-193, here 189. 
If, however, the concept of identity is interwoven with the religious other in the form of ascriptions of different orders to oneself and the other - both in the form of constructions and co-constructions - the theological understanding of identity is also expanded to the idea 'that religious identities always develop out of the interaction with alterities, i.e., other religious and worldview conceptual systems ${ }^{53}$. Thus, theologically as well, identity is always to be seen in relation to other contexts and other persons.

Another influential factor on the theological understanding of identity is the concept of God that always guides human thinking and acting. If one sees in God as primarily the guarantor of stability and immutability, this leads to denotations and connotations that impact the concept of identity differently than if God viewed as the ultimate orientation - represents possibilities, the other, changeability, and fragmentariness.

From the theological perspective, we can also mention on the theoretical level - in addition to the approaches discussed more fully above - the concept of multiple identities developed by Raimon Panikkar. ${ }^{54}$ This theory takes up the question of the identification with various religious traditions and manifests itself in, among other things, families whose members belong to different religious traditions. ${ }^{55}$ Perry Schmidt-Leukel is of the opinion that, since such phenomena are a matter of course in the current pluralistic religious and worldview conditions, one should speak rather of 'multireligious identity'56. Reinhold Bernhardt reminds us that the 'formation of patterns of individual and communal religious identity ${ }^{57}$ can be viewed less as the 'cognitive reception of pregiven systematic complexes of convictions and behaviour orientations'58 than something that occurs through narratives. Each person's identity is influenced, strengthened, disrupted, irritated, or built up by an abundance of narratives. The different traditions or narratives are placed in relation to each other; they penetrate each other

53 Dehn, Ulrich, Einleitung: Brauchen wir für den interreligiösen Dialog eine Theologie der Religionen? In: Id. (ed), Handbuch Dialog der Religionen. Christliche Quellen zur Religionstheologie und zum interreligiösen Dialog. Frankfurt/Main 2008, 13-27, here 13.

54 Cf. Nitsche, Bernhard, Raimon Panikkar. Multiple Identität als gelebte inter-intra-religiöse Transversalität. In: Bernhardt, Reinhold / Schmidt-Leukel, Perry (eds), Multiple religiöse Identität. Aus verschiedenen Traditionen schöpfen. Zurich 2008, 59-77, here 60.

55 Cf. Schnell, Tatjana, Religiosität und Identität. In: Bernhardt / Schmidt-Leukel (eds), Multiple religiöse Identität, 163-183, here 167.

56 Schmidt-Leukel, Perry, Multireligiöse Identität. Anmerkungen aus einer pluralistischen Sicht. In: Bernhardt / Id. (eds), Multiple religiöse Identität, 243-265, here $244 \mathrm{f}$.

57 Bernhardt, Reinhold, "Synkretismus" als Deutekategorie für multireligiöse Identitätsbildungen. In: Bernhardt / Schmidt-Leukel (eds), Multiple religiöse Identität, 267-290, here 287. 58 Ibid. 
without being dissolved into each other. ${ }^{59}$ Bernhardt says that it is precisely this that occurs in a high-quality interreligious dialogue.

Another point should be clarified here: the issue of multiple identities applies not only to religions but also to the - wider - area of worldviews.

\subsection{Theoretical Perspectives on Conflict and Conflict Potential}

\subsubsection{Approaches to the Concept of Conflict}

Conflicts can arise wherever people encounter each other. In most cases, conflicts do not need any special starting situations or conditions. Above all, ordinary conflicts, i.e., all conflicts that occur in everyday interactions between people, often arise from misunderstanding in communication. ${ }^{60}$ Accordingly, the conflict potential lies in disruptions within communication processes. ${ }^{61}$

To call a specific interaction a conflict depends on the concept of conflict and the concomitant theory that are hereby invoked. Generally, a distinction is made between psychological conflicts, thus conflicts that are psychological in nature, and social conflicts that arise within social frameworks between social actors like persons, groups, organisations, or states. ${ }^{62}$ With respect to conflicts in interreligious educational processes, social conflicts are of special interest to us in the analysis and interpretation of the empirical material. Here we concentrate on so-called everyday conflicts that can also have a religious or cultural stamp.

Etymologically, the term 'conflict' can be traced back to the Latin verb confligere ('collide' or 'meet'). Its meaning includes 'discord, dispute, strife [between persons, states, etc.] - and internal strife between motives, desires, aspirations ${ }^{63}$. Social conflicts include differences in interests and 'the disputes of differing intensity and violence between persons, groups, organisations that follow from those disagreements. ${ }^{64}$ The content of conflicts can be quite varied. Disa-

59 Cf. ibid., 289.

60 Cf. Zuschlag, Bernd / Thielke, Wolfgang, Konfliktsituationen im Alltag. Ein Leitfaden für den Umgang mit Konflikten in Beruf und Familie. Göttingen ${ }^{3} 1998,20$ f.

61 Cf. ibid., 34.

62 Cf. ibid.

63 Meyer, Joseph, Meyers großes Konversations-Lexikon: ein Nachschlagewerk des allgemeinen Wissens. Leipzig ${ }^{10} 1986,89$.

64 Ibid. 
greements regarding moral concepts or perspectives on life are thematised in conflicts, as are power relations and differences concerning power and status struggles. There are also different theories about the origins of conflict that depend on the academic discipline and respective perspective. ${ }^{65}$

The definition of the concept of conflict is determined by the respective theoretical approach and is quite a vague concept in the social sciences. This vagueness in turn has effects

on the levels on which conflict is thematised in theory, on possible topics regarding conflict and parties involved in conflict and on special forms of settling conflicts. ${ }^{66}$

In general, conflict is defined as a situation of competition

in which the parties are aware of the incompatibility of potential future positions and in which each party wishes to occupy a position that is incompatible with the wishes of the other. ${ }^{67}$

It also has to do with struggles rooted in various motives that contradictory aspirations, driving forces, or desires underlie. ${ }^{68}$ In summary, conflicts can be defined as a contest between contradictions (positions, values, faith issue, social status, desires, urges, expectations, etc.) that can lead to tension, strife, and even violence and war.

When the word 'conflict' is used in this book, it refers in the first place to tensions on the basis of which various positions and values become visible. Conflicts are thus found between two parties in the interaction

when two people want different things; they follow different goals, have different purposes, make different decisions, etc.; when the actions pursued in this or the goals of such action are mutually exclusive or cannot ... be reconciled ...; if the partners are thus unable to achieve an optimal result for both. ${ }^{69}$

65 Cf. ibid., 90.

66 Bonacker, Thorsten, Sozialwissenschaftliche Konflikttheorien. Einleitung und Überblick. In: Id. (ed), Sozialwissenschaftliche Konflikttheorien: eine Einführung. Wiesbaden ${ }^{3} 2008$, 9-29, here 9.

67 Boulding, Kenneth E., Conflict and Defense. A General Theory. New York 1962, 5.

68 Cf. Ulich, Dieter, Konflikt und Persönlichkeit: psychologische Modelle und ihre Bedeutung für die Pädagogik. Munich 1971; Zuschlag / Thielke, Konfliktsituationen im Alltag, 34.

69 Sachse, Rainer, Konflikt und Streit. Wie wir konstruktiv mit ihnen umgehen. Heidelberg 2017, 8. 
We define conflict potential as a contradiction concerning values, socialisation, and social position that can, in our view, lead to conflict; it is not visibly manifest but underlies conflicts that may arise.

Moreover, two different types of conflict can be distinguished. We speak of 'interaction conflicts' when both parties take part in the conflict and also bear responsibility for that conflict. ${ }^{70}$ 'Internal conflicts' are distinguished from that and describe conflicts that occur within an individual.

Conflicts always arise where people with different biographies, values, intentions, etc. encounter each other, both in the private and the professional domain. Conflicts are thus part of the 'normal' processes of interhuman interaction. The way conflicts are dealt with, how and if they are thematised determines the further course of interhuman encounters and (educational) processes.

As was already explained above in the section on 'identity', religion is a central marker of personal identity. If people with various religious values and accompanying biographies, life plans, and goals meet, for instance, in interreligious educational processes, the conflict potential increases. What this looks like, what the central 'areas of conflict' are, and how the concrete conflicts are expressed will be described in the empirical part of this book. In the following section, some theories of conflict will be introduced that are fundamental for this analysis.

\subsubsection{Interdisciplinary Perspectives on Conflict Theories}

Theories of conflict are embedded in various academic disciplines and represent subfields of political science, sociological, and psychological theories. ${ }^{71}$ These positions on social conflicts are related to each other systematically and can in turn be found in classical conflict theories - like the theories of Thomas Hobbes, Karl Marx, Max Weber, and Georg Simmel - and in conflict theories related to international relations theories, in sociological social theory, and in actor theories in social science. ${ }^{72}$

Social-scientific conflict theories seek on one hand to analyse the origin and development of violence and, on the other, predict future conflicts. According to these theories, conflicts occur on three levels. The macrolevel, for instance, con-

70 Cf. ibid., 7.

71 For a comprehensive overview and presentation of individual theories, see Bonacker, Sozialwissenschaftliche Konflikttheorien and Bonacker, Thorsten, Konflikttheorien. In: Kneer, Georg / Schroer, Markus (eds), Handbuch Soziologische Theorien. Wiesbaden 2013, 178-198.

72 Cf. Bonacker, Sozialwissenschaftliche Konflikttheorien, 16. 
cerns international political conflicts between states; on the mesolevel, conflicts between groups, such as religious or ethnopolitical conflicts, are examined. Here the focus is on mutual perception as well as on intra- and intergroup processes. On the microlevel, it is conflicts between individuals that are studied. Here, individual conduct and interaction processes are focused on. Conflicts arise between individuals or collectives but also within actors and collectives.

Whereas social-scientific theories examine the social foci, psychological, and social psychological conflict theories concentrate on social processes like communication between individuals and on psychological processes like thinking and feeling. ${ }^{73}$ Conflict theories thus explain conflicts on different levels. The choice of the corresponding theories and the concept of conflict therefore also determine the focus of the analysis.

In what follows, we will present an overview of the social psychological and psychological conflict theories that are relevant for this research project. The conflict theory of social identity from the field of social science is of particular interest. In addition, we will look at so-called intercultural and interreligious conflicts. Also, we will give an overview of the psychology of conflict so that we can explain the psychological processes that come to light in the expressions of the subjects interviewed.

\section{Social Psychological Perspectives on Conflicts: The Conflict Theory of Social Identity}

The essential building blocks of the theory of social identity by Henri Tajfel and John Turner ${ }^{74}$ were already introduced in the section above on identity. This social psychological theory explains processes and conflicts that can emerge between groups. Here the foremost question is: For what reasons do people distinguish their reference groups from other similar groups, usually by disparaging other groups? In various studies on perception, stereotyping, and prejudice, Tajfel and his colleagues observed that people always favour the in-group. ${ }^{75}$ The ingroup, according to their results, is preferred even when it goes against their own interests. The theory of social identity can be summarised in three fundamental assumptions. First, individuals strive 'to maintain a positive social identity that

73 Cf. Simon, Einführung in die Systemtheorie des Konflikts, 11.

74 Tajfel, Henri / Turner, John C., The social identity theory of intergroup behavior. In: Worchel, Stephen / Austin, William G. (eds), Psychology of intergroup relations. Chicago 1986, 7-24.

75 Cf. Zick, Andreas, Die Konflikttheorie der Theorie sozialer Identität. In: Imbusch / Zoll (eds), Sozialwissenschaftliche Konflikttheorien, 409-426, here 409. 
is completely defined by membership in a certain group. ${ }^{76}$ Second, social identity is based on processes, and the in-group must be demarcated from the outgroup in a positive way. Third, people either abandon the in-group if the concomitant social identity is unsatisfactory or reinforce the positive ascriptions to the in-group. ${ }^{77}$

The theory of social identity serves to analyse the motivations and needs that lead to conflicts. This is preceded by a specific understanding of conflicts as 'intergroup conflicts' where the focus is on the negotiation of social identity. According to this theory, conflicts either restore the social status of a group or effectuate an increase in the self-worth of a social group. Here Tajfel and Turner ${ }^{78}$ distinguish between objective and subjective as well as between explicit and implicit conflicts and request an analysis of the understanding of group conflicts. The extent of conflicts depends in turn, according to Tajfel and Turner, on different factors like the strength of one's identification with the group and the perceived threat to group identity. Beyond that, the comparable out-groups must show a specific similarity to the in-group (as is the case with similar religions) that depends, for its part, on the assessment of the status of the in-group and the out-group. In this theory, social conflicts have social identity as their aim, to prevent threats to the identity of one's own group or to maintain and reinforce the group's self-worth. ${ }^{79}$

The origin and maintenance of social prejudice and racist ideologies can also be demonstrated on the basis of this theory. Stereotypes are based on processes of categorisation whose goal is to favour the in-group and to distinguish itself from the out-group. In turn, they depend on the self-categorisation of someone within a social group. Stereotypes and prejudices thus have a cognitive function and are not automatisms. The cognitive function of stereotypes consists in constructing a clear image of the social world on the one hand and in stabilising one's positive self-image on the other. It therefore also has a 'value function'. ${ }^{80}$

Precisely in the interreligious encounter in which religious groups establish contact with each other, it is necessary to look at these dynamics of demarcation and differentiation and the degree of tension between the in-group and the outgroup. Conflict potential is found particularly in the preconceptions concerning the respective other religious groups that exist, in possible prejudices and stereotyping. In the assessment of the empirical materials therefore, preconceptions,

76 Ibid.,410.

77 Cf. ibid.

78 Cf. ibid.

79 Cf. ibid., $417 \mathrm{f}$.

80 Cf. ibid., $418 \mathrm{f}$. 
stereotypes and prejudices that became visible in the interviews were investigated and analysed. For successful interreligious collaboration, it is essential to identify and thematise precisely this conflict potential that lies in social interaction.

\section{Intercultural and Interreligious Conflicts in Educational Contexts}

In the area of interreligious education, questions of interculturality also play a central role. This concerns not only people with different religious socialisations but also people from different cultural backgrounds. In the area of education research as well as in social work, the theme of conflicts and the conflict potential with respect to cultural diversity is becoming more and more the focus of research. ${ }^{81}$ Here as well, the definition of the concept is also vague. The questions relevant for us here are: Where does the conflict potential lie, and what influence does the cultural background of those involved have on conflicts?

A theoretical explanatory model for this is provided by the communication theory of 'cultural conflict', which explains conflicts between actors from different cultures as conflicts in communication:

People from different backgrounds come into conflict with each other because their communication is affected by misunderstanding and by competing, often exclusive valuations. ${ }^{82}$

Different cultures thus also bring different 'conflict cultures' with them, which again increases the conflict potential if there is a great difference between the moral conceptions of the cultures in question. The 'culture-conflict theory' can also be transferred to the area of subcultures as well as to gender cultures, professional cultures, etc. ${ }^{83}$ This concept is criticised for pushing the determinist as-

81 See Bar-On, Dan, Die ,Anderen ' in uns. Dialog als Modell der interkulturellen Konfliktbewältigung. Hamburg 2003; Weiß, Anja, Was macht interkulturelle Konflikte aus? Kulturelle Differenzen, ethnische Identitäten und die Frage der Macht. In: Journal für Konflikt- und Gewaltforschung (2001) 2, 87-110; Weiße, Interreligiöse Bildung Europa; Jozsa / Knauth / Weiße (eds), Religionsunterricht, Dialog und Konflikt; Haumersen, Petra / Liebe, Frank, Multikulti: Konflikte konstruktiv. Trainingshandbuch. Mediation in der interkulturellen Arbeit. Mühlheim/Ruhr 1999. 82 Fechler, Bernd, Dialog der Anerkennung. Möglichkeiten und Grenzen der Mediation bei ,interkulturellen` Konflikten an der Schule. In: Kloeters, Ulricke / Lüddecke, Julian / Quehl, Thomas (eds), Schulwege in die Vielfalt. Handreichung zur Interkulturellen und Antirassistischen Pädagogik in der Schule. Frankfurt/Main 2003, 103-148, here 105.

83 Cf. ibid., 106. 
sumption that ascribes specific mentalities to conflicts and leaves other factors that encourage conflict out of consideration. ${ }^{84}$

Another theoretical concept for the explanation of conflicts in intercultural encounters presents the concept of a 'struggle for recognition' ${ }^{85} \mathrm{Here}$, the focus is less on cultural discrepancies than on power relations. Thus, conflicts were perceived as the results of different social positions that people take in a pluralistic society. These are related to both social status as well as legal and political aspects. ${ }^{86}$ This approach is relevant for the analysis of educational contexts insofar as the dynamics of status positions can be detected here as well.

Fechler points out, via the example of the school, that struggles for social recognition between young people frequently occur, which can be implemented by means of various strategies and considerably influence the social dynamics in a heterogenous school class. In the foreground here are themes of group affiliation and self-worth that are of particular importance to students who belong to minorities. The conflict potential increases in heterogenous classes through the teacher's attitude and how he/she deals with diversity. ${ }^{87}$

From a sociological perspective, this can be explained by the theory of established-outsider relations. ${ }^{88}$ Based on an empirical study they carried out, Norbert Elias and John L. Scotson describe the social dynamics in an English suburb that lead to the reinforcement of social inequality and power differences. The starting point for such dynamics is the observation that members of groups that feel superior to other groups with respect to their power position assess their qualifications and 'human qualities' as better and suggest to the less powerful that they are inferior. ${ }^{89}$ The 'established group' ascribes the worst properties of the worst members to the 'outsider group' as a whole and forms their own self-image through identification with the properties of their most positively assessed member. ${ }^{90}$ Referring to individual cases reinforces the opinion formed about the 'outsider group'. The foundation for the established-outsider figuration represents 'an unequal balance of power with the tensions that develop from that.'

84 Cf. ibid., 107.

85 Cf. Honneth, Axel, Kampf um Anerkennung. Zur moralischen Grammatik sozialer Konflikte. Frankfurt/Main ${ }^{6} 2010$.

86 Cf. Fechler, Dialog der Anerkennung, 108.

87 Cf. ibid., $111 \mathrm{f}$.

88 Cf. Elias, Norbert / Scotson, John L., Etablierte und Außenseiter. Frankfurt/Main 1993.

89 Cf. ibid., $7 \mathrm{f}$.

90 Cf. ibid., 13.

91 Ibid., 14. 
It is also the deciding factor that makes it possible for an established group to effectively stigmatise an outsider group. A group is able to effectively stigmatise another group only if it operates from a clear position of power that is denied to the stigmatised group. As long as that is the case, the collective stigma placed upon the outsider group remains. ${ }^{92}$

The strategies of stigmatisation are different, depending on the social nature of the group in question. They are often meaningless outside the respective context of the established-outsider relation.

Anja Weiß also refers to power and power asymmetry in her analysis of interreligious conflicts. She advocates the thesis

that the phenomena that are treated under the headings of intercultural or ethnic conflicts become so problematic only because of power asymmetries between the conflict parties. ${ }^{93}$

Weiß criticises the fact that power asymmetries are neglected in research on interculturality. Here she refers to Weber's concept of power, which defines power as 'the chance of a man or a number of men to realize their own will in a social action even against the resistance of others who are participating in the action. ${ }^{94}$

According to Weiß, political power relations in intercultural contexts are crucial for the question whether the interests of a specific ethnic group can be enforced. She refers here to political research into ethnic conflicts. ${ }^{95}$ Groups that find themselves in positions of political power have at their disposal the appropriate resources in conflict constellations to enforce their interests. So-called 'microsocial conflicts', conflicts that arise between individuals are, according to Weiß, subject to relations of dominance and inequality. Educational contexts in particular are stamped by the dynamics of power and inequality. Weiß points out, moreover, that 'for many students the state school system does not encourage learning but becomes a coercive instrument and that the selectivity of this system permanently harms precisely "difficult" students', ${ }^{96}$ instead of examining the structures and dynamics behind that difficulty.

Another approach, which can be used in social inequality relations and also in the intercultural context is, in Weiß' view, Pierre Bourdieu's concept of 'sym-

92 Ibid.

93 Weiß, Was macht interkulturelle Konflikte aus?, 89.

94 Weber, Max, Economy and Society: An Outline of Interpretative Sociology (ed. Guenther Roth and Claus Wittich, trans. Ephraim Fischoff et al.). Berkeley 1978, 926.

95 Cf. Hopmann, P. Terrence, The Negotiation Process and the Resolution of International Conflicts. Columbia 1996.

96 Weiß, Was macht interkulturelle Konflikte aus?, 90. 
bolic power' ${ }^{97}$ Bourdieu uses this term to describe all power structures that are based on neither immediate and public coercion nor on violence and are embedded in systems of meaning to such an extent that individuals' objective spaces of opportunity are internalised. The 'dominated ones' only want what is wanted by the 'dominating ones' or the system. This consolidates and at the same time instrumentalises culturally conditioned relations of inequality. In studies on intercultural and interreligious educational processes, it is therefore necessary to unmask the power structures lying behind them in order to assess accordingly the conflict potential that is influenced by them at the same time.

\section{The Psychological Concept of Conflict}

Finally, even though political and social factors are indispensable in conflict analysis, we will now look at microprocesses, thus the psychological aspects of conflicts. In the foreground here is the question how conflicts are manifested on the level of thinking and feeling and thereby become expressed in social interaction. A psychological perspective can also provide insight into the attitudes and behavioural motives that underlie conflicts since "personal attitudes and behavioural motives in the sense of motivations for actions ... are the significant constituent elements of conflict in the end.'98

Above all, the actors' various needs and motivations for are relevant in everyday conflicts. Abraham Maslow's so-called 'need pyramid' represents a theory for understanding human needs. ${ }^{99}$ According to Maslow, human needs can be described on five levels that determine everyday life and interactional processes. These are physiological needs like sleep, nourishment, oxygen, etc.; physical, mental, and material needs for security; social needs for family, friendship, sexuality, belonging, etc., individual needs like trust, esteem, self-confirmation, success, freedom, and independence as well as the need for self-realisation. ${ }^{100}$ According to Bernd Zuschlag and Wolfgang Thielke, conflicts arise particularly in ordinary communication, for example in negotiations, through precisely these fundamental needs being either unfulfilled or fulfilled in a limited way, which can lead to setbacks. ${ }^{101}$ Therefore, according to Zuschlag and Thielke, 'what pre-

97 Bourdieu, Pierre, Die verborgenen Mechanismen der Macht. Hamburg 2015.

98 Zuschlag / Thielke, Konfliktsituationen im Alltag, 50.

99 Cf. Maslow, Abraham H., Motivation und Persönlichkeit. Reinbek ${ }^{15} 1981$.

100 Cf. ibid.

101 Cf. Zuschlag / Thielke, Konfliktsituationen im Alltag, 54. 
cise needs this conversation partner has at this moment needs to be discovered in detail in each case with sensitivity ${ }^{\prime 102}$.

A range of theories and strategies can be found particularly in the field of business conflict management or in communication training, for guiding conversations by exploring and identifying personal needs and motives for acting. ${ }^{103}$

Psychology offers several models that attempt to explain conflict and its interpsychic conditionality and constitution. In addition to the most important conflict model, which goes back to the founder of psychoanalysis Sigmund Freud, in which tensions can be traced back to opposing urges between different aspects of the individual, ${ }^{104}$ psychology itself can be partially understood as the 'psychology of conflict'. ${ }^{105}$ Psychology sees conflict potential on the internal psychological levels especially in the also well-known everyday ambivalences between feeling and thinking that underly the psychodynamics of conflict. The level of feeling is mentioned here in particular insofar as the effect of feelings on the origin and development of both individual and social conflicts are of decisive importance from a psychological perspective. Moreover, feelings play a central role in the origin of social systems, such as, for example, the formation of communities and belonging, and they also play a significant part in the dissolution of those communities. ${ }^{106}$ This 'co-reflection' on precisely these psychological perspectives is also helpful in the analysis of interreligious educational processes to the extent that 'internal psychological conflicts' in communication become clear and individual needs influence them.

As is clear here, conflicts and the conflict potential can be researched from different perspectives. The analysis of conflicts and the conflict potential in interreligious educational processes requires an open, multi-perspectival or interdisciplinary approach that incorporates - in addition to theological and religious pedagogical aspects, sociological, political, and (social) psychological aspects in order to understand the complexity of the themes in a comprehensive way.

102 Ibid.

103 An overview of different approaches and theories of conflict can be found in Zuschlag / Thielke, Konfliktsituationen im Alltag, in chapter B: Konflikt-Analyse, -Diagnose und -Bewältigung.

104 With the model of the so-called psychic apparatus, Freud describes three distinct psychic components that are related to and interact with each other. The 'id' here represents the instinctive drives in the individual that are opposed to the 'superego', the internalised and socialised compulsions. The thus conflicting urges are brought into balance by a third component (cf. Freud, Sigmund, Abriss der Psychoanalyse. Einführende Darstellungen [reprint]. Frankfurt/ Main ${ }^{42009) .}$

105 Cf. Simon, Einführung in die Systemtheorie des Konflikts, 52.

106 Cf. ibid., 59. 


\subsection{Our Conception of Identity, Conflict, Interreligiosity, Religious Education and Religious Didactics}

In this section we will offer - in connection with the state of research and the theoretical foundations - a short overview of the use of the five concepts of identity, conflict, interreligiosity, religious education and religious didactics in this study.

\section{Identity}

As described above, ${ }^{107}$ the concept of identity is a key term in the context of interreligious education. In particular, people and institutions that have misgivings about interreligious endeavours often argue that a stable (religious) identity formation is fundamental and necessary before any interreligious encounter can occur.

From the perspective of an interreligious religious education that focuses on inter- and transreligious education or teaching and learning processes, forms of reasoning and concepts associated with them are urgently needed that assume a progressive development of identity towards a stable essential core. In contrast, from the viewpoint of this study, the following can be proposed: first, we should keep in mind that, in the current pluralistic world, children encounter religious, cultural, and social identities already in infancy and then increasingly in kindergarten and school and thus also experience and apply the most varied ascriptions to themselves and to others. Religious and cultural plurality and the corresponding relations and social ascriptions are thus given in the earliest stages of childhood already. The individual is challenged to deal with that in his/her education. Another requirement is related to the increasing scientific knowledge with respect to the concept of identity. Precisely sociological and also religious pedagogical and theological studies ${ }^{108}$ consider a multi-perspectival concept of identity to be more suitable. This approach is based on concepts of social ascriptions or constructions, subjectifications, and multiple identities or the idea of fragments. ${ }^{109}$

With this critical understanding of identity - and thus with more recent scientific data - in our project we link up with scientific interreligious religious ed-

107 Cf. chapter 2.1.

108 On this, see the discussion in chapter 2.1.2.

109 Cf. Keupp, Identitätskonstruktionen; Foucault, Michel, Subjekt und Macht. In: Id. (ed), Analytik der Macht. Frankfurt/Main 2005, 240 -263; Bernhardt / Schmidt-Leukel (eds), Multiple religiöse Identität. 
ucation and religious didactics. Following Henri Tajfel and John C. Turner, we understand identity fundamentally as a social construction in whose development both the religious in-group and the religious out-group participate, the former through self-ascriptions and the latter through ascriptions by others. Following Heiner Keupp, we understand identities not as stable, finished entities with a fixed essential core but as entities that are characterised by dynamic flexible features and a fragmentary patchwork nature. Here, in accordance with the work of theological writers like Reinhold Bernhardt, ${ }^{110}$ Raimon Panikkar, and Bernhard Nitsche, the significance of the transitory, transversal, and thus potential religious boundary areas will come into view. ${ }^{111}$

\section{Conflict}

Following the multi-dimensional explanation of the semantic fields of the term conflict, ${ }^{112}$ we will make a few brief remarks here on aspects that are essential to our concept of conflict in this study.

The first remark concerns the concept of conflict and its connotations. Given all other specific facets worked out above regarding the concept of conflict, one general aspect should not be forgotten. The concept of conflict often has negative connotations from the outset, above all in the context of religions as well as in everyday life. In contrast, we argue for a 'more neutral' use of the concept of conflict, which can be indicated by the expression 'conflict potential' or 'what gives rise to conflict'. Here we can include 'movements' of various kinds that encounter each other from various perspectives, that intersect or cross each other and at first glance - do not 'fit' or can be brought into relation or connection with each other or 'be' integrated. They can, for example, represent different 'logics' in the sense of intellectual, perceptive, or reflective logics that cannot - in any case a priori - be subsumed under one denominator, or include different interests, strivings, habits, practices, and goals. In this sense, what intervenes or mediates can also be understood as what give rise to conflict, something that introduces another element into the usual situation - a new meaning, a current struggle, a sudden expectation, etc. Whereas conflicts manifest themselves in perceivable ways, for example in the wake of explicit differences of opinion, confrontations, or disputes, the conflict potential or what gives rise to conflict rep-

110 Bernhardt / Schmidt-Leukel (eds), Multiple religiöse Identität.

111 Cf. Nitsche, Raimon Panikkar.

112 On this, see the discussion in chapter 2.2. 
resents a latent foundation that may not, however, always be visible or lead inevitably to manifest, observable conflicts.

The second remark concerns the negative connotations of the concept of conflict. Only against the background of this basic understanding of conflict can the so-called conflictual aspect, viewed as neutral rather than good or bad, be unfolded in the various detailed aspects so that one can speak in scientifically about a psychological, a sociological, a theological, or a religious educational dimension. On the general level of what gives rise to conflict, it is 'normal' that conflicts arise, especially in contexts of plurality and heterogeneity. That there are always movements that contradict or conflict with each other is simply part of life. In this sense, conflict processes must not be controlled - that is not at all possible. Rather, they should be observed, analysed, processed, or discussed.

In this process, a subjective positioning occurs sooner or later as a matter of course. The subject places him-/herself in relation to what befalls him/her or the conflict processes he/she triggers. If these affirm his/her concepts, actions, plans, or goals, they are judged positively. If they do not affirm them but destroy them sometimes, he/she then assesses these processes negatively. Thus, various levels and dimensions come into play, and those differentiations that we discussed above become relevant.

\section{Interreligious Education - Interreligious Learning}

In our presentation of the state of research, we focused on the concept of interreligiosity. We analysed the concepts multireligious and interreligious and maintained that in the religious educational context 'multireligious' entails religious studies, whereas 'interreligious' emphasises communal learning - it concerns communal education in religious educational and religious didactical contexts. ${ }^{113}$ Thus, in this study we will use the concept of interreligiosity for the encounter between Christian and Muslim students, teachers and supervisors, and communal learning. We are not, however, suppressing the distinctions here between the different religions or between the adherents of the different religions nor are we advocating simple co-existence.

In this sense, we understand interreligious education and interreligious learning as a learning that is sensitive to religion, a learning that also acknowledges the importance of religion in public life. Moreover, we conceive of interreligious education as contingency-sensitive, as treating the position of the reli-

113 On this, see the discussion in chapter 1.1. 
gious other respectfully and humbly. Interreligious learning and interreligious education should also 'be understood as a multi-perspectival learning that moves between inter- and intrareligious perspectives in a critical-creative way.' ${ }^{114}$

\section{Religious Education}

Regarding the term religious education, we follow the dominant view and understand religious education as theories of religious and worldview education and training processes (sometimes also including the concept of learning), their presuppositions, and individual-personal, collective-social as well as societal and economic-political conditions.

Religious education is widely viewed as a theological discipline at theological institutes or faculties, ${ }^{115}$ whereby its connection with other sciences (educational sciences, sociology, psychology, etc.) is strongly emphasised. With respect to these, however, different views exist concerning what is important for theology: material views (the subject matters for theology), formal views (it is the theological perspective that turns religious education into a theological discipline) and organisational views (religious education/religious didactics is found in the 'concert' of the theological sciences; this means it is also a theological science). ${ }^{116}$

In the context of this study, we share the second view: the theological exists in the perspective under which the corresponding religious-worldview educational processes will be viewed. It should be noted that this educational process can be implicit or explicit, formal or informal, institutionalised or less institutionalised. A series of fields of action are thereby discussed: family, elementary education, secondary school, professional training, continuing education, adult education, community formation, education for seniors, etc. The religious educational area of responsibility in our study is related to the interreligious area, as

114 Danzl, Interreligiös oder multireligiös?, 47.

115 Cf. Englert, Rudolf, Wissenschaftstheorie der Religionspädagogik. In: Ziebertz, Hans-Georg / Simon, Werner (eds), Bilanz der Religionspädagogik. Düsseldorf 1995, 147-174, here 152.

116 For the concept of 'material' see: Ziebertz, Hans-Georg, Religionspädagogik und Empirische Methodologie. In: Schweitzer, Friedrich / Schlag, Thomas (eds), Religionspädagogik im 21. Jahrhundert. Gütersloh 2004, 209-222 and Kraml, Martina, What about knowing? Überlegungen zur Konzeptualisierung religionspädagogisch-empirischer Forschung im Gespräch mit ,anderen Orten. In: Österreichisches Religionspädagogisches Forum (2011) 1, 32-38, here 33f. The formal perspective is, in turn, also brought into play by Hans-Georg Ziebertz. According to his models, what makes a science is not the material object but the formal object, the perspective, from which the object is viewed (cf. Ziebertz, Religionspädagogik und Empirische Methodologie, 221). 
has been discussed above, and includes the praxis fields of elementary, secondary, and tertiary education as well as extra-curricular contexts.

\section{Religious Didactics}

Religious didactics deals, in our view, with the theory of the conceptualisation, implementation, and evaluation of educational processes - or, formulated more specifically, of teaching and learning processes in educational institutions.

Interreligious didactics reflects the conceptualisation, guiding, and implementation of religious collaboration or interreligious teaching and learning processes in the specific fields of action. In our view, didactics focuses on the conceptual level, not the methodological. The methodological approach is a subarea of the conceptual that is concerned with the means (methods and social forms) of the teaching and learning processes. Before we can tackle the question of means in the sense of methods, we must first provide the conceptual part, a theological-didactic orientation, and properly delimit the topic of our study. Only if the topic - as a result of the didactic steps of analysis and determination of an objective or competence - is known and is clear can the process be structured further.

From our perspective, the subject of religious didactics raises the question of quality. This refers on the one hand to the issue of multi-perspectivity: Should in addition to the substantive dimension - other dimensions be included, such as the subjective dimension, the social dimension, or the contextual dimension? On the other hand, we must also take into account the process that indicates which planning phases in the process are being completed - such as, for example, the analysis phase, the goal, issue, and competence phases, the phase of formulating of the theme and indication of the structure (methods, media, social forms, etc.). Moreover, we also need to look at the characteristics of the learning process and how the evaluation phase is conceptualised. 